\title{
Substance P-induced pulmonary vascular remodelling in precision cut lung slices
}

\author{
J. Springer*,\#, A. Fischer ${ }^{\#}$
}

Substance P-induced pulmonary vascular remodelling in precision cut lung slices. J. Springer, A. Fischer. (C) ERS Journals Ltd 2003.

ABSTRACT: Substance P (SP) levels have been reported to be elevated in animal models of pulmonary hypertension (PH) and chronic administration of SP has been shown to induce $\mathrm{PH}$. In the present study, the role of reactive oxygen species (ROS) as mediators of SP-induced vascular remodelling and $\mathrm{PH}$ was analysed.

Vascular remodelling was induced in precision cut lung slices by treatment with $\left[\operatorname{Sar}^{9}, \operatorname{Met}^{11}\left(\mathrm{O}_{2}\right)\right]-S P$ and by hypoxia. Functional analyses were used to study the chronic [Sar', $\left.{ }^{9}{ }^{11}\left(\mathrm{O}_{2}\right)\right]-\mathrm{SP}$-mediated effects on proliferation and generation of ROS, which is involved in the pathogenesis of $\mathrm{PH}$. The nonpeptide NK-1 receptor antagonist CP 96345 was used to block $\left[\operatorname{Sar}^{9}, \operatorname{Met}^{11}\left(\mathrm{O}_{2}\right)\right]-S P$ effects. ROS generation and proliferation was assayed by the dichloroflourescein-diacetate method and incorporation of 5-Bromo-2'-Deoxyuridine, respectively.

ROS generation was induced by either $1 \%$ oxygen $(5.8$-fold $)$ or $\left[\operatorname{Sar}^{9}, \operatorname{Met}^{11}\left(\mathrm{O}_{2}\right)\right]-\mathrm{SP}(8-$ fold) in normoxia in the alveolar region. $\left[\mathrm{Sar}^{9}, \mathrm{Met}^{11}\left(\mathrm{O}_{2}\right)\right]-\mathrm{SP}$ did not further elevate ROS levels in hypoxia, suggesting an oxygen-dependent mechanism. High ROS levels stabilised hypoxia inducible factor-1 $\alpha$ and induced proliferation in small vessels (4.3fold in hypoxia and $\left.\left[\operatorname{Sar}^{9}, \operatorname{Met}^{11}\left(\mathrm{O}_{2}\right)\right]-\mathrm{SP}\right)$. Both ROS generation and proliferation were blocked in the presence of $\mathrm{CP}$ 96345, nitroblue-tetrazolium, $N$-acetylcysteine- and diphenylene-iodonium.

The results presented in this study indicate a role of SP in proliferative events associated with vascular remodelling in pulmonary hypertension.

Eur Respir J 2003; 22: 596-601.
*Anatomy and Cell Biology, Justus-LiebigUniversity, Giessen and ${ }^{\#}$ Division of Allergy Research, Dept of Pediatric Pneumology and Immunology, Charité, Humboldt-University, Berlin, Germany.

Correspondence: J. Springer, Division of Allergy Research, Dept of Pediatric Pneumology and Immunology, Biomedical Research Center, Virchow-Campus, Charité, HumboldtUniversity, Augustenburger Platz 1, 13353 Berlin, Germany.

Fax: 4930450559951

E-mail: jochen.springer@charite.de

Keywords: Precision cut lung slices pulmonary hypertension reactive oxygen species substance $\mathrm{P}$

vascular remodelling

Received: March 132003

Accepted after revision: May 72003
The pathophysiological pathways involved in the development of primary pulmonary hypertension $(\mathrm{PH})$ and of the more common secondary $\mathrm{PH}$ are still unclear. A common feature of all forms of PH is pulmonary vascular remodelling and right ventricular hypertrophy. The main cause for $\mathrm{PH}$ in humans is alveolar hypoxia [1] as a result of chronic lung diseases leading to secondary PH [2]. Hypoxia induces the generation of reactive oxygen species (ROS) in various cells, including pulmonary vascular smooth muscle cells (VSMC), and causes proliferation of VSMCs and adventitial fibroblasts [3]. The mechanism involves the ubiquitously expressed, hypoxia sensitive transcription factor hypoxia inducible factor (HIF)-1 $\alpha$, which is stabilised by ROS [1]. HIF- $1 \alpha$ activation is maximal at an oxygen $\left(\mathrm{O}_{2}\right)$ concentration of $0.5-2 \%$ [4], whereas it is rapidly degraded by the ubiquitinproteasome pathway under normoxic conditions [5].

Several observations suggest that substance $\mathrm{P}(\mathrm{SP})$ is involved in the pathophysiological events leading to the vascular remodelling observed in PH. Pharmacological application of a stable SP analogue induces vascular remodelling, leading to thickening of the media and to the development of $\mathrm{PH}$ in rats, while pretreatment with the tachykinin NK-1 receptor antagonist CP 96345 has been shown to prevent SPinduced $\mathrm{PH}$ [6]. In patients suffering from $\mathrm{PH}$, SP fails to cause the marked endothelium-dependent vasodilatation that is observed in healthy subjects [7]. While the vasodilator response has been shown to be mediated through activation of the NK-1 receptor and release of NO and prostacyclins [8], the mechanism of SP-induced remodelling remains unclear. In a rat model of monocrotaline-induced inflammation of pulmonary vessels, ROS were suggested to increase levels of SP [9], possibly by inactivation of the SP-degrading enzyme neutral endopeptidase (EC 3.4.24.11).

Due to the similarities of hypoxia and SP-induced vascular remodelling and $\mathrm{PH}$, the hypothesis that $\mathrm{SP}$ exerts its effects by generating ROS was addressed in this study. Using precision cut lung slices (PCLS) of mice as a model, the effects of SP on ROS generation and HIF-1 $\alpha$ stabilisation, as well as the effects on proliferation in pulmonary vessels, were examined. PLCS combine the advantages of cell culture in an organoid system. They are mostly used for pharmacological $[10,11]$ or toxicological studies and allow the use of human tissue (for review see [12]).

\section{Methods}

\section{Tissue processing}

After killing the animals by cervical dislocation, $500 \mathrm{U}$ heparine (Hoffmann-La Roche, Grenzach-Wyhlen, Germany) and $1 \mathrm{mM}$ glyceryltrinitrate (Merk, Darmstadt, Germany) were injected into the right ventricle. The pulmonary vascular bed was then perfused with $10 \mathrm{~mL}$ of a pre-warmed ringer containing $0.2 \%$ procainhydrochloride (weight/volume; Merck), $500 \mathrm{U}$ heparine and $10 \mu \mathrm{M}$ glyceryltrinitrate. The lungs were then instilled with 1\% low-melting agarose (Biorad, Munich, 
Germany) via the trachea and the thoracic viscera was transferred into a chilled ringer. PCLS were cut at a thickness of $250 \mu \mathrm{m}$ using a vibratome (Leica, Bensheim, Germany). The sections were cultivated in minimum essential medium (MEM; Gibco, Heidelberg, Germany) without additional serum at $38^{\circ} \mathrm{C}$, which was gassed with 21 and $1 \% \mathrm{O}_{2}$, respectively. The medium was changed after $4 \mathrm{~h}$ to remove the dissolved agarose.

\section{Reactive oxygen species assay}

ROS production was assayed in PCLS of 11 mice in two sets with dichloroflourescein-diacetate (DCF-DA; Alexsis, Grünberg, Germany), as described previously [13]. Groups of six animals were incubated for $1 \mathrm{~h}$ in the presence of $1 \mu \mathrm{M}$ DCF-DA and gassed with 21 or $1 \% \mathrm{O}_{2}$. Under both $\mathrm{O}_{2}$ conditions, $5 \mathrm{nM}\left[\operatorname{Sar}^{9}, \mathrm{Met}^{11}\left(\mathrm{O}_{2}\right)\right]-\mathrm{SP}$, in the presence and absence of the nonpeptide NK-1 receptor antagonist $\mathrm{CP}$ $96345(1 \mu \mathrm{M})$, was added. Control sections were incubated with $1 \mu \mathrm{M}$ CP 96345 or MEM alone. In a second set of experiments, the effects of ROS scavengers, $1 \mu \mathrm{M}$ nitroblue tetrazolium (NBT; Sigma, Deisenhofen, Germany) and $1 \mu \mathrm{M}$ $\mathrm{N}$-acetylcysteine (NAC; Sigma), and of the flavoprotein inhibitor diphenylene iodonium (DPI; $10 \mu \mathrm{M}$; Calbiochem, Bad Soden, Germany), which inhibits the major ROSgenerating enzymes, were examined in five animals under normoxic conditions only.

The sections were then fixed in $4 \%$ paraformaldehyde (PFA) for $20 \mathrm{~min}$ washed in $0.1 \mathrm{M}$ phosphate buffered saline three times for $10 \mathrm{~min}$ at $4^{\circ} \mathrm{C}$ and kept in the dark. Confocal laser scanning microscopy was used to evaluate the relative amount of transformed DCF-DA and thus the amount of ROS generated. In five fields of parenchyma, the number of ROS-generating cells per field was quantified in a blinded fashion. The fields were chosen at random across the sections at the same level, but care was taken that no large airways or vessels were visible.

\section{Proliferation assay}

Groups of a new set of 12 animals were incubated in serumfree MEM containing $1 \times 10^{-4} \mathrm{M}$ 5-Bromo-2'-Deoxyuridine (BrdU) and gassed with 21 or $1 \% \mathrm{O}_{2}$ for $72 \mathrm{~h}$. Under both $\mathrm{O}_{2}$ conditions, $5 \mathrm{nM}\left[\operatorname{Sar}^{9}, \operatorname{Met}^{11}\left(\mathrm{O}_{2}\right)\right]-\mathrm{SP}$, in the presence and absence of $1 \mu \mathrm{M}$ CP 96345, was added. Additionally, the effects of $1 \mu \mathrm{M}$ NBT, $1 \mu \mathrm{M}$ NAC and $10 \mu \mathrm{M}$ DPI on $\left[\operatorname{Sar}^{9}, \operatorname{Met}^{11}\left(\mathrm{O}_{2}\right)\right]-\mathrm{SP}$ regulated proliferation activity were investigated under normoxia.

Sections were then fixed in 4\% PFA for $45 \mathrm{~min}$ and

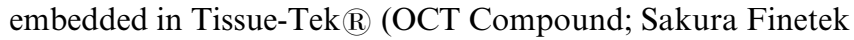
Europe BV, Zoeterwoude, the Netherlands) for subsequent sectioning at $10 \mu \mathrm{m}$ with a cryostat (Leica, Weiterstadt, Germany) for immunohistochemistry. Detection of incorporated BrdU requires denaturing of the double-stranded deoxyribonucleic acid. Sections were incubated in $0.1 \mathrm{~N}$ $\mathrm{HCl}$ at $4{ }^{\circ} \mathrm{C}$ for $10 \mathrm{~min}$ to remove histones, transferred into $2 \mathrm{~N} \mathrm{HCl}$ at room temperature for $30 \mathrm{~min}$ and neutralised with $0.1 \mathrm{M}$ borax ( $\mathrm{pH} \mathrm{8.5)}$ for $10 \mathrm{~min}$. BrdU incorporation was visualised with a monoclonal antibody (DAKO, Hamburg, Germany) and a mouse-on-mouse kit (DAKO) followed by strepavidin Texas Red (Amersham, Freiburg, Germany), and was then counter stained with a polyclonal rabbit vonWillebrand Factor antibody (DAKO) detected by fluorescein isothiocyanate-labelled goat antiserum (Dianova, Hamburg, Germany) to identify the vasculature and 4', 6-Diamidino-2phenyindole, diactate (Sigma) to identify the nuclei. The number of BrdU-positive nuclei in vascular profiles in 25 fields, containing two to six vessels, per experimental condition per animal was assayed in a blinded fashion with a fluorescence microscope (DMRA2; Leica, Weiterstadt, Germany) at 200× magnification. The results are given as BrdU-positive nuclei per vascular profile.

\section{Immunohistochemical localisation of hypoxia inducible factor- $1 \alpha$}

Parallel cryostat sections of $72-\mathrm{h}$ incubations were used to localise HIF-1 $\alpha$, using a monoclonal antibody (1:50; DPC Biermann, Bad Nauheim, Germany), which was visualised with an ARKit (DAKO) and strepavidin Texas Red.

\section{Statistical analysis}

Data were analysed using the Kruskal-Wallis and the Mann-Whitney U-test and $\mathrm{p} \leqslant 0.05$ was considered significant. The error is given as SEM.

\section{Results}

\section{Generation of reactive oxygen species}

To determine the effect of SP on ROS generation, PCLS were incubated with DCF-DA for $1 \mathrm{~h}$ under 21 and $1 \% \mathrm{O}_{2}$, the latter serving as a positive control for ROS generation and vascular remodelling, as an increase in ROS production under hypoxia has been reported and chronic alveolar hypoxia is frequently used to induce $\mathrm{PH}$ in animal models. Five nM $\left[\mathrm{Sar}^{9}, \mathrm{Met}^{11}\left(\mathrm{O}_{2}\right)\right]-\mathrm{SP}$, in the presence and absence of $1 \mu \mathrm{M} \mathrm{CP}$ 96345, as well as $1 \mu \mathrm{M}$ CP 96345 alone, was added to the medium. ROS production was very low under normoxic conditions (figs. 1 and 2) while hypoxia caused a strong and
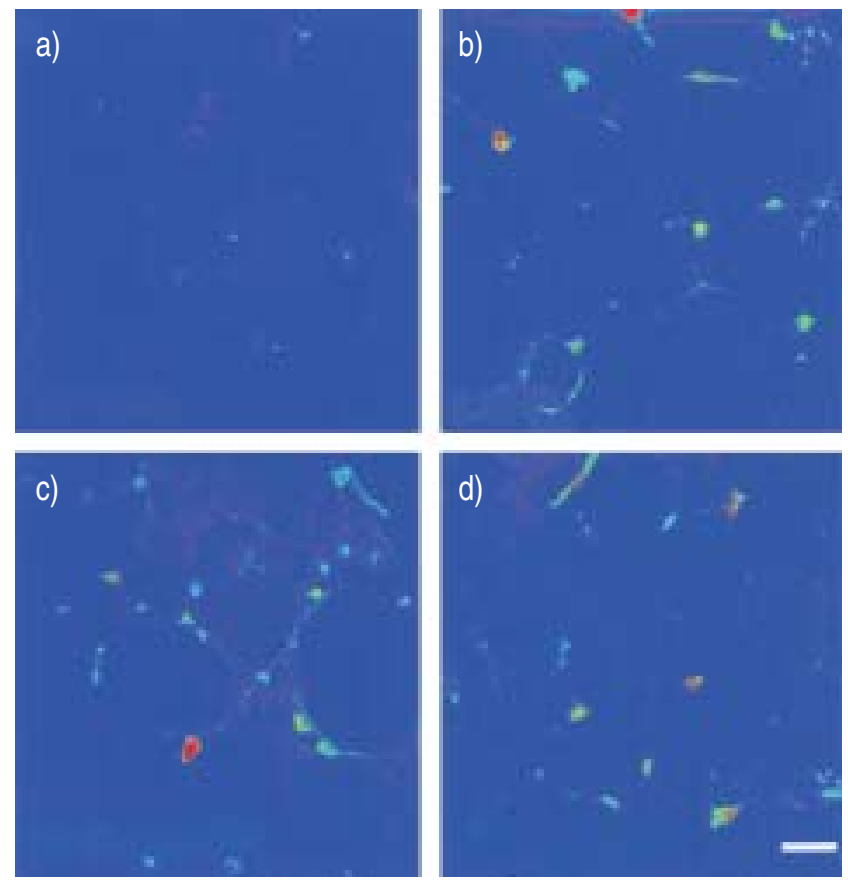

Fig. 1. - Pseudo-coloured images of reactive oxygen species generation (over $1 \mathrm{~h}$ ) in the parenchyma of vital lung sections in the presence of $21 \%$ oxygen (a and $c), 1 \%$ oxygen $(b$ and $d)$ and $\left[\operatorname{Sar}^{9}, \operatorname{Met}^{11}\left(\mathrm{O}_{2}\right)\right]-$ substance $\mathrm{P}$ (c and d). Scale bar $=20 \mu \mathrm{m}$. 


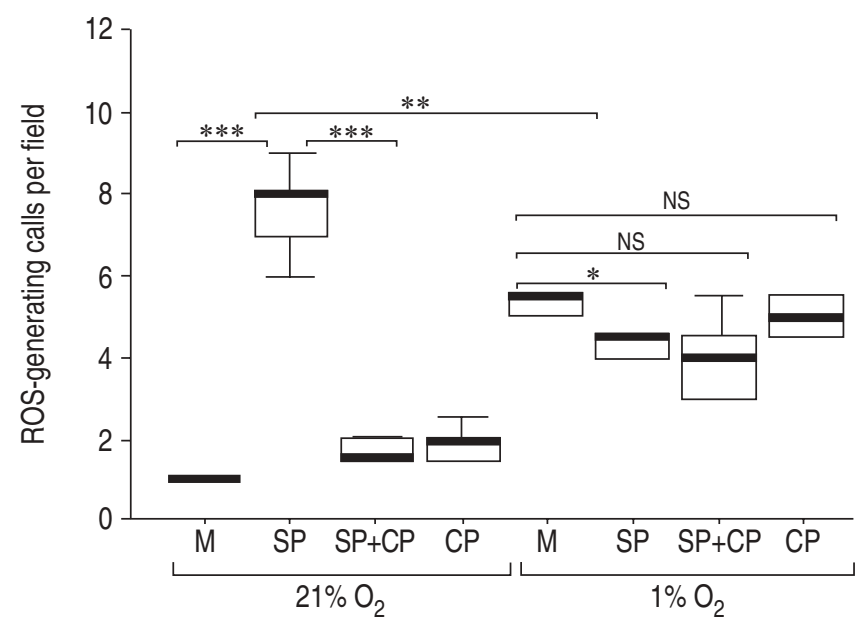

Fig. 2.-Quantitative assay of reactive oxygen species (ROS)-generating cells as a mean of five fields per animal $(n=5)$. M: medium; $C P$ : $C P$ $96345(1 \mu \mathrm{M})$; SP: $\left[\operatorname{Sar}^{9}, \operatorname{Met}^{11}\left(\mathrm{O}_{2}\right)\right]-\mathrm{SP}(5 \mathrm{nM}) .{ }^{* * *}: \mathrm{p} \leqslant 0.001 ; * *$ : $\mathrm{p} \leqslant 0.01 ; *: \mathrm{p} \leqslant 0.05 ;$ NS: nonsignificant.
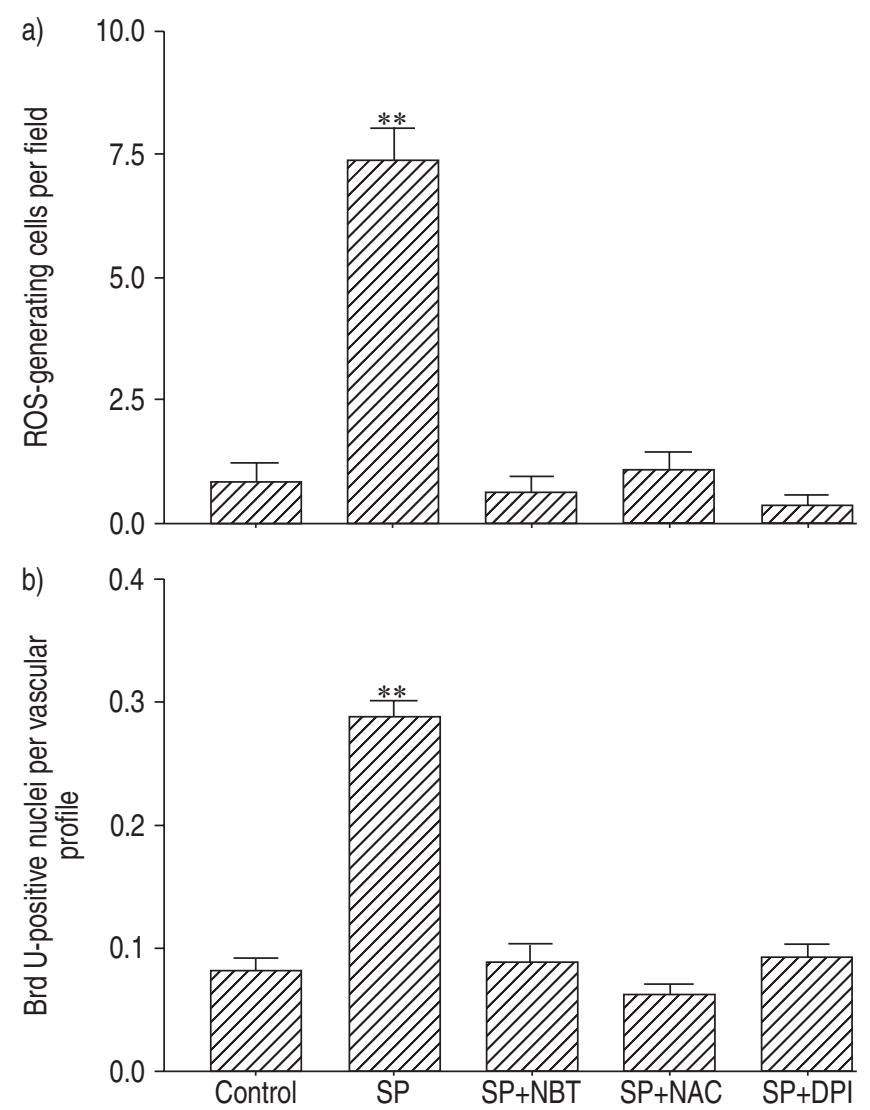

Fig. 3.-Inhibition of substance $P$ (SP)-induced reactive oxygen species (ROS) generation (over $1 \mathrm{~h}$ ) and proliferative activity (over $72 \mathrm{~h}$ ) in precision cut lung slices by radical scavengers and reduced nicotinamide adenine dinucleotide phosphate oxidase inhibition. a) Quantification of ROS generation cells as mean of five fields per animal $(n=5)$. b) quantification of proliferative activity as a mean of 25 fields per experimental condition and animal $(n=5)$. DPI: diphenylene iodonium $(1 \mu \mathrm{M})$; NBT: nitroblue tetrazolium $(1 \mu \mathrm{M})$; NAC: $N$-acetycysteine $(1 \mu \mathrm{M}) ; \mathrm{SP}:\left[\operatorname{Sar}^{9}, \operatorname{Met}^{11}\left(\mathrm{O}_{2}\right)\right]-\mathrm{SP}(5 \mathrm{nM}) .{ }^{* *}: \mathrm{p} \leqslant 0.01$.

significant increase of ROS generation in individual cells within the alveolar region (figs. 1 and 2) but not in larger vasculature, which was identified using phase contrast microscopy. Sections incubated with SP displayed a similar ROS-generation pattern under normoxic conditions as compared to hypoxia (figs. 1 and 2), yet the number of ROS-producing cells was significantly higher than in hypoxia (fig. 2). Subjecting sections to SP and hypoxia reduced the number of positive cells as compared to hypoxia alone (fig. 2). Incubating the sections with the NK-1 receptor antagonist CP $96345(1 \mu \mathrm{M})$ for $15 \mathrm{~min}$ prior to the administration of $\left[\operatorname{Sar}^{9}, \operatorname{Met}^{11}\left(\mathrm{O}_{2}\right)\right]$-SP dramatically reduced the number of ROS-producing cells under normoxia (fig. 2) but did not influence ROS generation under hypoxic conditions (fig. 2). Application of the antagonist alone had no effect on the generation of ROS in this system under either condition (fig. 2). As predicted, incubation of the lung sections with NBT, NAC and DPI led to a complete suppression of DCFDA reduction or radical production caused by [Sar ${ }^{9}$, $\operatorname{Met}^{11}\left(\mathrm{O}_{2}\right)$ ]-SP under normoxic conditions (fig. 3a).

\section{Proliferative activity}

Incubation of the sections under normoxic conditions led to low proliferative activity in small blood vessels (figs. 4 and 5), as quantified by BrdU incorporation into the nuclei over a period of $72 \mathrm{~h}$ and subsequent immunohistochemistry. Small vasculature was identified by immunohistochemical detection of the von-Willebrand factor (data not shown). Subjecting the sections to hypoxia over the same period of time induced a significant increase in proliferation in the small vasculature ( $<50 \mu \mathrm{m}$; figs. 4 and 5), whereas larger blood vessels did not show any proliferative activity under either $\mathrm{O}_{2}$ concentration $\left(>150 \mu \mathrm{m}\right.$; data not shown). Five nM [Sar $\left.{ }^{9}, \operatorname{Met}^{11}\left(\mathrm{O}_{2}\right)\right]-S P$ strongly induced proliferation within the media of the small vasculature in normoxia (figs. 4 and 5), which reached the same level observed in hypoxia (fig. 5), however, [Sar ${ }^{9}$
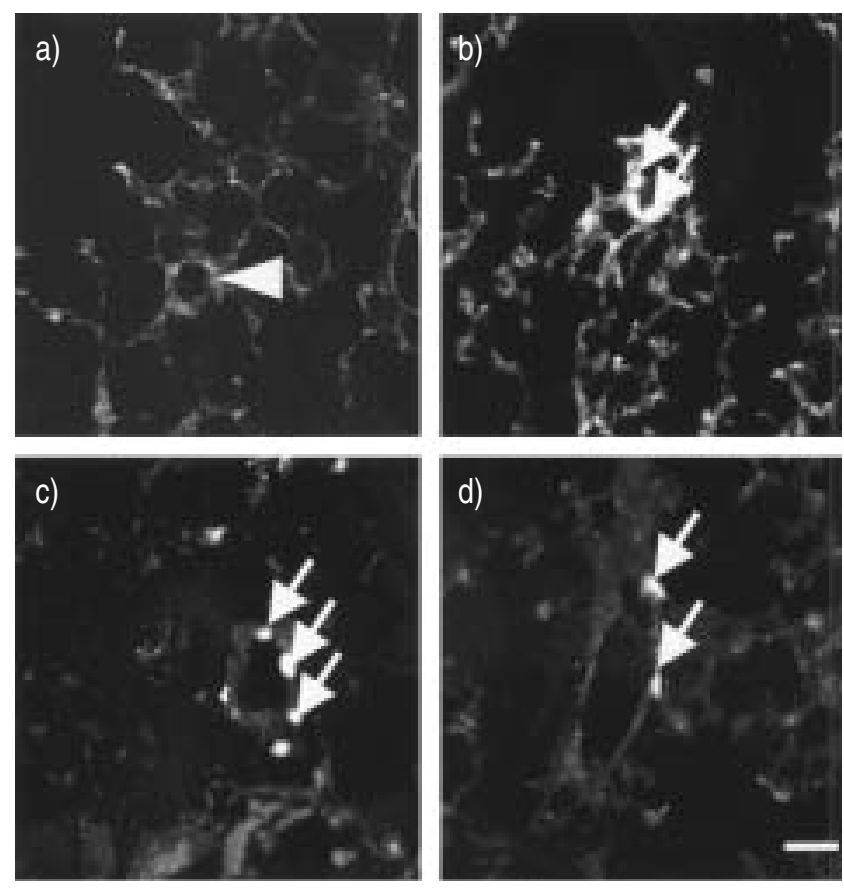

Fig. 4.-Detection of proliferation (over $72 \mathrm{~h}$ ) in small pulmonary vessels assayed by 5-Bromo-2'-Deoxyuridine (BrdU) incorporation localised by immunohistochemistry in the presence of $21 \%$ oxygen (a and c), 1\% oxygen (b and d) and $\left[\operatorname{Sar}^{9}, \operatorname{Met}^{11}\left(\mathrm{O}_{2}\right)\right]$-substance $\mathrm{P}$ (c and d). Arrows: BrdU-positive nuclei; arrow head: vessel. Scale bar $=20 \mu \mathrm{m}$. 


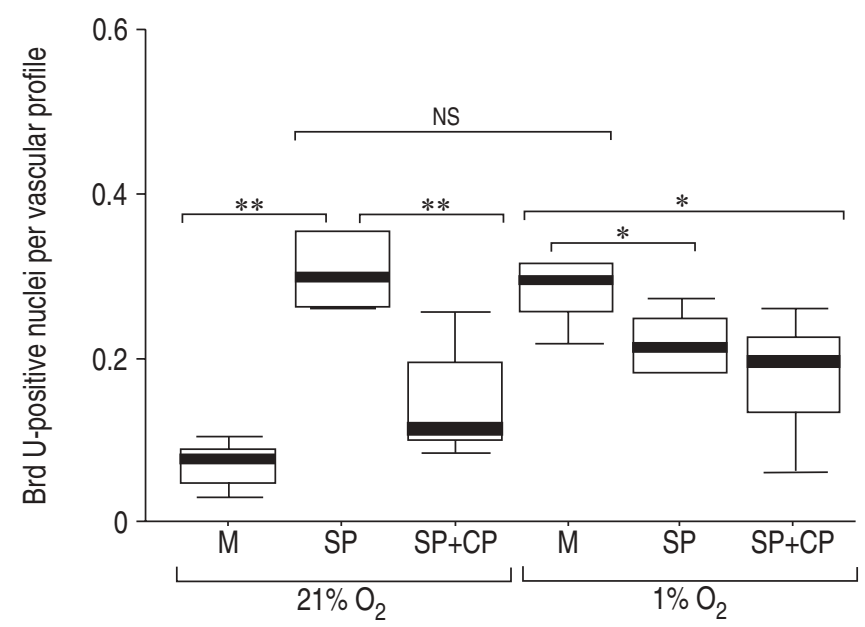

Fig. 5.-Quantitative assay of proliferation as a mean of 25 fields per experimental condition and animal $(n=6)$. M: medium; CP: CP 96345 $(1 \mu \mathrm{M})$; SP: $\left[\operatorname{Sar}^{9}, \mathrm{Met}^{11}\left(\mathrm{O}_{2}\right)\right.$ ]-SP $(5 \mathrm{nM})$. **: $\mathrm{p} \leqslant 0.01 ; *: \mathrm{p} \leqslant 0.05 ; \mathrm{NS}$ : nonsignificant.

$\left.\operatorname{Met}^{11}\left(\mathrm{O}_{2}\right)\right]$-SP significantly decreased proliferation when administered in hypoxia (figs. 4 and 5). The $\left[\operatorname{Sar}^{9}, \operatorname{Met}^{11}\left(\mathrm{O}_{2}\right)\right]-\mathrm{SP}$ effect under normoxic conditions was strongly antagonised to almost the control level by $1 \mu \mathrm{M}$ CP 96345 (fig. 5). In hypoxia the decrease in proliferation caused by $\left[\operatorname{Sar}^{9}, \operatorname{Met}^{11}\left(\mathrm{O}_{2}\right)\right]-\mathrm{SP}$ was not reversed by administration of the antagonist (fig. 5).

The $\left[\operatorname{Sar}^{9}, \operatorname{Met}^{11}\left(\mathrm{O}_{2}\right)\right]$-SP-induced proliferative activity under normoxic conditions was completely blocked by either scavenging the ROS using NBT or NAC, or by inhibiting flavoproteins by DPI (fig. 3b).

\section{Detection of hypoxia inducible factor $-1 \alpha$}

As predicted, the transcriptionfactor HIF-1 $\alpha$ could not be detected in the lung parenchyma under normoxic conditions (fig. 6a). Subjecting the sections to hypoxia stabilised HIF-1 $\alpha$ in cells of the lung parenchyma (fig. 6b). Localisation was confined to the nuclei only (fig. $6 \mathrm{~b}$ and c). In lung sections incubated with $\left[\operatorname{Sar}^{9}, \operatorname{Met}^{11}\left(\mathrm{O}_{2}\right)\right]-\mathrm{SP}$ under normoxic conditions, HIF-1 $\alpha$ was detected in the parenchyma, as well as a small number of vessels (fig. 6c), whereas larger vessels did not display any HIF-1 $\alpha$ stabilisation (data not shown).

\section{Discussion}

Proliferative events are hallmark pathological features in $\mathrm{PH}$. These include proliferation of VSMC, fibroblasts and endothelial cells, leading to the remodelling observed in $\mathrm{PH}$ [14]. As a result, abnormal proliferative activity in the pulmonary vascular bed can be used as an indication of vascular remodelling.

The present study has addressed the effects of SP on the generation of ROS and vascular remodelling indicated by proliferation, without attempting to characterise the proliferating cells, in PCLS, which display beating cilia in the bronchi and can be pharmacologically stimulated after $72 \mathrm{~h}$ in culture (data not shown). This is consistent with the results observed by MARTIN et al. [10]. Furthermore, it has been shown that PCLS maintain structural integrity for up to 60 days, although the endothelium may loose its integrity after 7 days [15].

The application of SP to lung sections leads to ROSmediated vascular remodelling, indicated by an increase in proliferative activity. This is consistent with the results obtained by chronic treatment of rats with SP [6]. As observed for hypoxia [16], SP treatment in a 72-h culture of PCLS is a valuable model to study vascular remodelling in the pulmonary artery, which allows a marked reduction in time and animal numbers.

In monocrotaline-induced $\mathrm{PH}$, ROS were shown to increase the levels of SP [9]. The results of this study show that oxygen radicals are generated upon either exposure of PCLS to severe hypoxia or low doses of $\left[\operatorname{Sar}^{9}, \operatorname{Met}^{11}\left(\mathrm{O}_{2}\right)\right]$ SP over a 1-h period in (peri-) vascular cells. The effects of $\left[\operatorname{Sar}^{9}, \operatorname{Met}^{11}\left(\mathrm{O}_{2}\right)\right]-\mathrm{SP}$ were mediated by the NK-1 receptor, since the antagonist CP 96345 dramatically reduced the number of ROS-generating cells. Subjecting the lung sections to hypoxia and SP did not have a synergistic effect on the ROS generation, indicating that ROS production caused by $\mathrm{SP}$ is $\mathrm{O}_{2}$ dependent.

Proliferation of vascular cells occurred only in small $(<50 \mu \mathrm{m})$, resistance-type vessels, which is the part of the pulmonary vascular bed responsible for the pressure elevation observed in PH [3]. Hypoxia leads to an increased ROS production in various cells by either the membrane bound reduced nicotinamide adenine dinucleotide phosphate (NADPH) oxidase complex $[17,18]$ or an increase of mitochondrial ROS generation [13]. ROS generated by NADPH oxidases have been shown to induce proliferation in VSMC of the human aorta by activation of extracellular signal-regulated protein
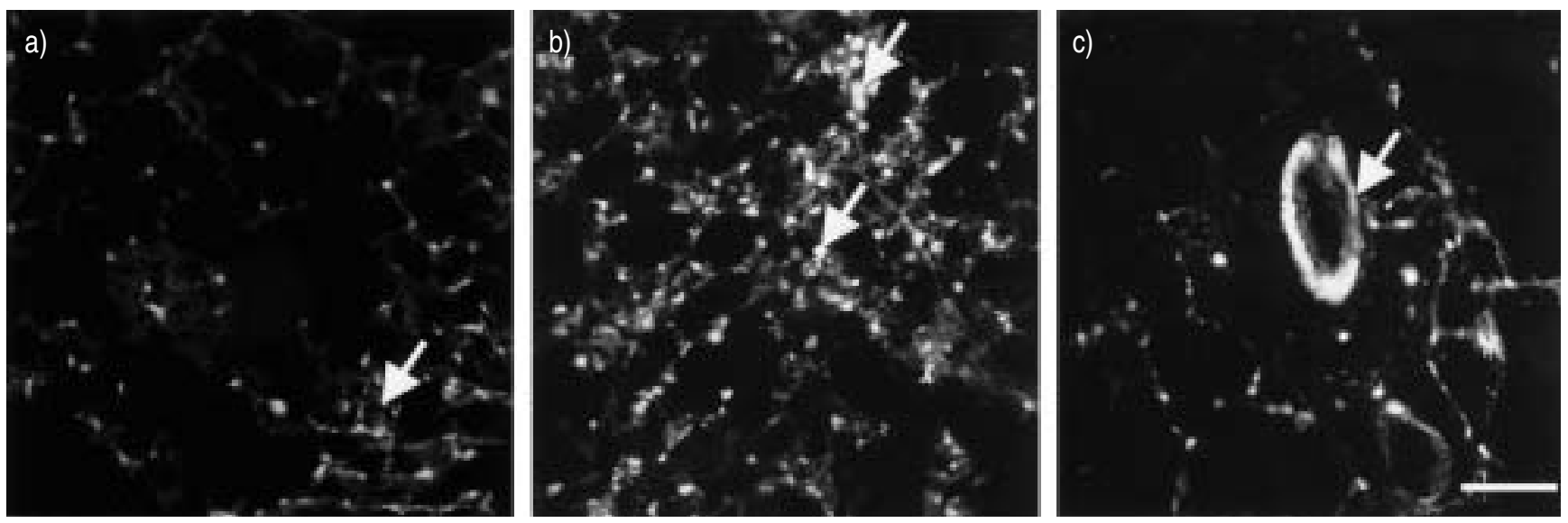

Fig. 6. - Immunohistological detection of hypoxia inducible factor- $1 \alpha$ after $72 \mathrm{~h}$ in sections subjected to a) normoxia $\left(21 \%\right.$ oxygen $\left.\left(\mathrm{O}_{2}\right)\right)$, b) hypoxia $\left(1 \% \mathrm{O}_{2}\right)$ and c) $\left[\mathrm{Sar}^{9}, \mathrm{Met}^{11}\left(\mathrm{O}_{2}\right)\right]$-substance $\mathrm{P}$ in normoxia. Arrows: vessels. Scale bar: $50 \mu \mathrm{m}$. 
kinase (ERK)-2 with subsequent expression of c-fos via the p2 $1^{\text {ras }} /$ Raf-1/MEK2 pathway [19], whereas mitochondriallygenerated ROS usually lead to cell death [20, 21]. Indeed, activation of NADPH oxidase by hypoxia has been described in VSMC [22]. Low doses of ROS have been shown to induce proliferation in a variety of cells [23], including VSMC [24].

The proliferative events of the vasculature triggered by $\left[\mathrm{Sar}^{9}, \mathrm{Met}^{11}\left(\mathrm{O}_{2}\right)\right]-\mathrm{SP}$ also seem to be mediated by the NK-1 receptor, as administration of CP 96345 did not only inhibit ROS generation but also proliferation of the vasculature. Since the proliferative activity induced by $\left[\operatorname{Sar}^{9}, \mathrm{Met}^{11}\left(\mathrm{O}_{2}\right)\right]-\mathrm{SP}$ is blocked by the ROS scavengers NBT and NAC as well as the flavoprotein inhibitor DPI, it appears to be likely that the proliferative response to $\left[\mathrm{Sar}^{9}, \mathrm{Met}^{11}\left(\mathrm{O}_{2}\right)\right]-\mathrm{SP}$ is mediated by ROS generation.

Inhibition of membrane-related ROS generation by DPI or scavenging ROS with NBT has been shown to lead to a complete halt in the hypoxia-induced proliferation in the pulmonary vasculature [16]. Furthermore, CP 96345 has been shown to inhibit the development of $\mathrm{PH}$ in rats, given by daily injections of $\left[\operatorname{Sar}^{9}, \mathrm{Met}^{11}\left(\mathrm{O}_{2}\right)\right]-\mathrm{SP}$ [6]. Compared to hypoxia alone, proliferation of vascular cells was lower when $\left[\mathrm{Sar}^{9}, \mathrm{Met}^{11}\left(\mathrm{O}_{2}\right)\right]-\mathrm{SP}$ was added in hypoxia, suggesting somewhat antagonistic effects, which may be due to the activation of different signal transduction pathways. The proliferative events triggered by ROS in response to hypoxia and $\left[\operatorname{Sar}^{9}, \operatorname{Met}^{11}\left(\mathrm{O}_{2}\right)\right]-\mathrm{SP}$ under normoxic conditions may involve stabilisation of HIF-1 $\alpha$, as the protein was identified by immunohistochemistry. The distribution of the HIF-1 $\alpha$-positive nuclei in the parenchyma was identical in hypoxia or [Sar $\left.{ }^{9}, \mathrm{Met}^{11}\left(\mathrm{O}_{2}\right)\right]$-SP incubation, yet the vessels displayed a stronger immunoreactivity in sections incubated with $\left[\operatorname{Sar}^{9}, \operatorname{Met}^{11}\left(\mathrm{O}_{2}\right)\right]-S P$, which, again, may be due to the activation of different signal transduction pathways.

The ubiquitously expressed HIF- $1 \alpha$ is a global regulator of hypoxic gene expression although it is thought to interact with cell type-specific regulatory factors to evoke a specific cell reaction, e.g. erythropoietin or vascular endothelial growth factor expression [25]. ROS may also lead to the induction of the proto-oncogenes c-myc and c-fos [26], which in turn activate the cell cycle via induction of cyclin expression [27]. Other studies show a protein kinase C-mediated activation of the phosphatidylinositol 3 phosphate kinase/mammalian target of ramamycin/p $70^{\mathrm{S} 6 \mathrm{~K}}$ kinase signal transduction pathway in pulmonary VSMC [28], which may be triggered by ROS $[29,30]$. ROS may also activate ERK-5 (BMK-1) via the c-Src kinase [31], which is activated in hypoxia and is thought to be an activator kinase of HIF-1 $\alpha$ [32].

In summary, this study provides evidence for an effect of substance $\mathrm{P}$ on the remodelling processes involved in the pathophysiology of pulmonary hypertension. During this process, reactive oxygen species-induced increases of substance P levels, as shown by CHEN et al. [9], and substance $\mathrm{P}$-mediated reactive oxygen species generation, shown in this study, may lead to a vicious circle that perpetuates pulmonary hypertension. The resulting vascular remodelling is associated with an impaired vasodilator response of the resistance vessels. These mechanisms occur locally and do not involve central reflexes, as the effects were observed in living precision cut lung slices.

\section{References}

1. Semenza GL, Agani F, Feldser D, et al. Hypoxia, HIF-1, and the pathophysiology of common human diseases. $A d v$ Exp Med Biol 2000; 475: 123-130.

2. Barnes PJ. Chronic obstructive pulmonary disease. $N$ Engl $J$ Med 2000; 343: 269-280.
3. Rabinovitch M, Gamble W, Nadas AS, Miettinen OS, Reid L. Rat pulmonary circulation after chronic hypoxia: hemodynamic and structural features. Am J Physiol 1979; 236: H818-H827.

4. Wenger RH, Gassmann M. HIF-1 and the molecular response to hypoxia in mammals. In: Environmental Stress and Gene Regulation. Springer-Verlag, New York, USA, 1999; pp. 25-45.

5. Huang LE, Gu J, Schau M, Bunn HF. Regulation of hypoxia-inducible factor $1 \alpha$ is mediated by an $\mathrm{O}_{2}$-dependent degradation domain via the ubiquitin-proteasome pathway. Proc Natl Acad Sci USA 1998; 95: 7987-7992.

6. Chen LW, Chen CF, Lai YL. Chronic activation of neurokinin-1 receptor induces pulmonary hypertension in rats. Am J Physiol 1999; 276: H1543-H1551.

7. Maggi CA, Giachetti A, Dey RD, Said SI. Neuropeptides as regulators of airway function: vasoactive intestinal peptide and the tachykinins. Physiol Rev 1995; 75: 277-322.

8. Pedersen KE, Buckner CK, Meeker SN, Undem BJ. Pharmacological examination of the neurokinin-1 receptor mediating relaxation of human intralobar pulmonary artery. J Pharmacol Exp Ther 2000; 292: 319-325.

9. Chen MJ, Chiang LY, Lai YL. Reactive oxygen species and substance $\mathrm{P}$ in monocrotaline-induced pulmonary hypertension. Toxicol Appl Pharmacol 2001; 171: 165-173.

10. Martin C, Uhlig S, Ullrich V. Videomicroscopy of methacholineinduced contraction of individual airways in precision-cut lung slices. Eur Respir J 1996; 9: 2479-2487.

11. Martin C, Ullrich V, Uhlig S. Effects of the thromboxane receptor agonist U46619 and endothelin-1 on large and small airways. Eur Respir $J$ 2000; 16: 316-323.

12. Parrish AR, Gandolfi AJ, Brendel K. Precision-cut tissue slices: applications in pharmacology and toxicology. Life Sci 1995; 57: 1887-1901.

13. Höhler B, Lange B, Holzapfel B, et al. Hypoxic upregulation of tyrosine hydroxylase gene expression is paralleled, but not induced, by increased generation of reactive oxygen species in PC12 cells. FEBS Lett 1999; 457: 53-56.

14. Eddahibi S, Morrell N, d'Ortho MP, Naeije R, Adnot S. Pathobiology of pulmonary arterial hypertension. Eur Respir J 2002; 20: 1559-1572.

15. Siminski JT, Kavanagh TJ, Chi E, Raghu G. Long-term maintenance of mature pulmonary parenchyma cultured in serum-free conditions. Am J Physiol 1992; 262: L105-L110.

16. Springer J, Juricko J, Braun-Dullaeus RC, Fischer A, Kummer W. Hypoxia induces proliferation in the pulmonary vascular bed in vitro. Am J Resp Crit Care Med 2000; 161: A422.

17. Acker H, Bolling B, Delpiano MA, Dufau E, Gorlach A, Holtermann $\mathrm{G}$. The meaning of $\mathrm{H}_{2} \mathrm{O}_{2}$ generation in carotid body cells for $\mathrm{pO}_{2}$ chemoreception. J Auton Nerv Syst 1992; 41: 41-51.

18. Fandrey J, Frede S, Jelkmann W. Role of hydrogen peroxide in hypoxia-induced erythropoietin production. Biochem $J$ 1994; 303: 507-510.

19. Bhunia AK, Han H, Snowden A, Chatterjee S. Redoxregulated signaling by lactosylceramide in the proliferation of human aortic smooth muscle cells. J Biol Chem 1997; 272: $15642-15649$.

20. Jabs T. Reactive oxygen intermediates as mediators of programmed cell death in plants and animals. Biochem Pharmacol 1999; 57: 231-245.

21. Deshpande SS, Angkeow P, Huang J, Ozaki M, Irani K. Racl inhibits TNF-alpha-induced endothelial cell apoptosis: dual regulation by reactive oxygen species. Faseb $J$ 2000; 14 : $1705-1714$.

22. Marshall C, Mamary AJ, Verhoeven AJ, Marshall BE. Pulmonary artery NADPH-oxidase is activated in hypoxic pulmonary vasoconstriction. Am J Respir Cell Mol Biol 1996; 15: 633-644.

23. Burdon RH. Superoxide and hydrogen peroxide in relation to mammalian cell proliferation. Free Radic Biol Med 1995; 18: $775-794$. 
24. Demiryurek AT, Wadsworth RM. Superoxide in the pulmonary circulation. Pharmacol Ther 1999; 84: 355-365.

25. Guillemin K, Krasnow MA. The hypoxic response: huffing and HIFing. Cell 1997; 89: 9-12.

26. Rao GN, Berk BC. Active oxygen species stimulate vascular smooth muscle cell growth and proto-oncogene expression. Circ Res 1992; 70: 593-599.

27. Braun-Dullaeus RC, Mann MJ, Dzau VJ. Cell cycle progression: new therapeutic target for vascular proliferative disease. Circulation 1998; 98: 82-89.

28. Krymskaya VP, Penn RB, Orsini MJ, et al. Phosphatidylinositol 3-kinase mediates mitogen-induced human airway smooth muscle cell proliferation. Am J Physiol 1999; 277: L65-L78.
29. Ushio-Fukai M, Alexander RW, Akers M, et al. Reactive oxygen species mediate the activation of Akt/protein kinase B by angiotensin II in vascular smooth muscle cells. $J$ Biol Chem 1999; 274: 22699-22704.

30. Bae GU, Seo DW, Kwon HK, et al. Hydrogen peroxide activates p70(S6k) signaling pathway. J Biol Chem 1999; 274: 32596-32602.

31. Abe J, Kusuhara M, Ulevitch RJ, Berk BC, Lee JD. Big mitogen-activated protein kinase 1 (BMK1) is a redoxsensitive kinase. J Biol Chem 1996; 271: 16586-16590.

32. Mukhopadhyay D, Tsiokas L, Zhou XM, Foster D, Brugge JS, Sukhatme VP. Hypoxic induction of human vascular endothelial growth factor expression through c-Src activation. Nature 1995; 375: 577-581. 